\title{
Net primary production and carbon cycling in coast redwood forests of central California
}

\author{
Christopher Potter \\ NASA Ames Research Center, Mountain View, USA; chris.potter@nasa.gov
}

Received 13 May 2012; revised 16 June 2012; accepted 3 July 2012

\begin{abstract}
A simulation model to estimate net primary productivity (NPP) has been combined with in situ measurements of soil carbon dioxide $\left(\mathrm{CO}_{2}\right)$ emissions and leaf litter pools in three coast redwood forest stands on the central California coast. Monthly NPP was predicted from the CASA model using 250-meter resolution vegetation index (VI) inputs. Annual NPP was predicted to vary from $380 \mathrm{~g} \cdot \mathrm{C} \cdot \mathrm{m}^{-2} \cdot \mathrm{yr}^{-1}$ to $648 \mathrm{~g} \cdot \mathrm{C} \cdot \mathrm{m}^{-2} \cdot \mathrm{yr}^{-1}$ at central coast redwood sites over the years 2007 to 2010. Measured soil respiration rates at between 0.5 to $2.2 \mathrm{~g} \cdot \mathrm{C} \cdot \mathrm{m}^{-2} \cdot \mathrm{d}^{-1}$ were slightly below the range of measurements previously reported for a second-growth mixed (redwood and Douglasfir) conifer forests. Although warm monthly temperatures at the southern-most redwood forest sites evidently results in elevated stress levels to sustained redwood growth into the dry summer months of June and July, these redwood stands appear to sequester $\mathrm{CO}_{2}$ from that atmosphere into forest biomass for a net positive ecosystem carbon balance each year.
\end{abstract}

Keywords: Carbon; Forest Ecosystems; Remote Sensing; MODIS

\section{INTRODUCTION}

Coast redwood [Sequoia sempervirens (D. Don) Endl.] is restricted in its historical distribution to a narrow belt of land extending about $50 \mathrm{~km}$ inland from the Pacific coast at latitudes ranging from approximately $42^{\circ} \mathrm{N}$ to $36^{\circ} \mathrm{N}$ [1]. The coast redwood is the tallest living tree species and notably long-lived [2]. The historical and cultural significance of coast redwood makes the conservation and scientific study of these forests a continuing priority for ecologists $[3,4]$. The redwood ecoregion has been identified by the World Wildlife Fund as being in the highest conservation priority class among ecoregions in the United States, based on biological uniqueness, conservation status, and impending threats [2,5].
Although mature redwoods have thick bark that allows the trees to survive moderately intense fires [6], logging removed the majority of coast redwood stands over the past 200 years [4]. Nonetheless, climate change may be among the most serious threats to the remaining Pacific coast redwood forests. For instance, Johnstone and Dawson [7] reported physiological evidence that coast redwood and other ecosystems along the United States west coast may be increasingly drought stressed under a summer climate of reduced fog frequency and greater evaporative demand. Understanding the current rates of redwood forest productivity and carbon cycling are therefore essential as baseline values against which future changes can be evaluated.

In this study, we present the results of the NASACASA (Carnegie-Ames-Stanford Approach) model, which predicts net primary productivity $(N P P)$ fluxes using inputs of climate and satellite imagery as a means to understand coast redwood carbon cycling at the landscape level. Our CASA model [8-11] has been designed to estimate monthly patterns in carbon fixation and plant biomass increments using moderate spatial resolution $(250 \mathrm{~m})$ satellite remote sensing of surface vegetation characteristics and driven with spatially interpolated climate.

Satellite data from NASA's (Moderate Resolution Imaging Spectroradiometer) MODIS instrument have been applied to forest production and carbon cycling studies for over a decade [12]. Direct input of satellite vegetation index (VI) "greenness" data from the MODIS sensor into ecosystem simulation models can now be used to estimate spatial variability in monthly $N P P$, biomass accumulation, and litter fall inputs to soil carbon pools [10]. We have combined CASA model results from 2007 to 2010 with in situ measurements of soil carbon dioxide $\left(\mathrm{CO}_{2}\right)$ emissions and leaf litter pools to estimate baseline carbon cycling rates in redwood forest stands on the central California coast (Figure 1).

\section{REGIONAL GEOGRAPHY AND STUDY SITE DESCRIPTIONS}

Redwood stands on the central coast are situated 


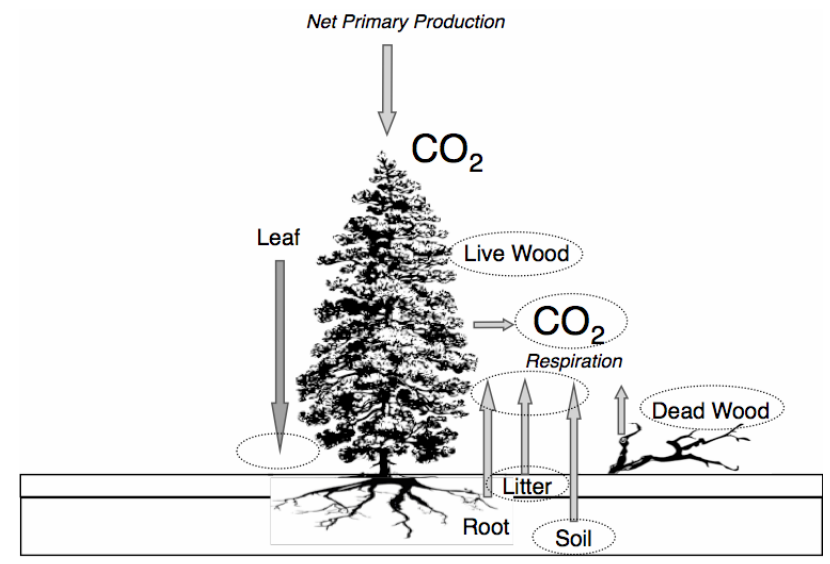

Figure 1. Forest carbon cycle diagram that represents the framework for analysis of coast redwood stands in this study. Fluxes of $\mathrm{CO}_{2}$ are shown in italics and arrows. Carbon storage pools in the plant-soil system are identified (in circles as measurable by sampling at the stand level).

where the wet, cooler climate of the northern California region meets the dry, warmer climate of the southern region [13]. Consequently, the setting for this study is located at the nexus of modern climate change geography in the western United States. The topography of this region is dominated by the steepest coastal gradient in North America. The highest mountains in the area form a wall behind coastal hillsides, which effectively traps cooler marine air. This can lead to the formation of steep elevation gradients in air temperature regimes, humidity and other climate factors. The advection of marine stratus layers over land profoundly moderates the coastal climate by reducing insolation and temperatures, raising humidity, and supplying water directly to the landscape [7].

Seasonality on the California central coast is characterized by moderate diurnal variations in winter air surface temperatures, several extreme rain events $(>50$ $\mathrm{mm} /$ day) each year, and high sustained wind speeds ( $>40$ miles/hr). The wet winter season (November-February) is followed by a warm season with wider diurnal variations in air temperatures and continuously high relative humidity. Rainfall is highly seasonal, with the vast majority of precipitation days occurring as winter season storms. There are typically between 50 - 70 days with measurable rainfall $(>0.5 \mathrm{~mm} /$ day $)$ each year, but between the months of April and October, there are usually less than 3 days per month when any measurable rainfall occurs [14]. During a single year, there are typically between 2 and 9 days during which rain totals that exceed $25 \mathrm{~mm} /$ day (about one inch) of precipitation, and another 5 to 12 days during which rain totals that exceed $12 \mathrm{~mm} /$ day (about one-half inch) of precipitation.

Within the northern section of the central coast redwood belt in California, three study site locations (Table 1) were selected and described below where with in situ
Table 1. Coast redwood site characteristics.

\begin{tabular}{lcc}
\hline Site Name & Latitude Longitude & Approx. Age (Years) \\
\hline UCSC Campus & $37.005^{\circ} \mathrm{N}, 122.059^{\circ} \mathrm{W}$ & 90 \\
Brazil Ranch & $36.358^{\circ} \mathrm{N}, 121.882^{\circ} \mathrm{W}$ & 150 \\
Big Creek Reserve & $36.067^{\circ} \mathrm{N}, 121.583^{\circ} \mathrm{W}$ & $>150$ \\
\hline
\end{tabular}

measurements of soil $\mathrm{CO}_{2}$ emissions and leaf litter pools have been made since 2008. The northern-most redwood site was located at the University of California at Santa Cruz (UCSC) Campus Natural Reserve. Measurement plots were established in second-growth redwood forests of less than 100 years in age [15], located off the Fuel Break Road on the East Slope section of the UCSC Campus Natural Reserve. Sandy loam soils derived from sandstone predominate the forested stands.

A second coast redwood study site was located on the 490-hectare Brazil Ranch in the Los Padres National Forest [14]. Brazil Ranch is situated in Big Sur on the coast of Monterey County, about 20 miles south of the city of Carmel. Previously called the Bixby Ocean Ranch, Brazil Ranch is named for the pioneer families who worked parts of the property for nearly a century as a farm, ranch, and dairy operation. Topography of the Brazil Ranch varies from the flat coastal marine terrace at 60 meters elevation to above 350 meters elevation on the exposed western ridges overlooking the Pacific Ocean. A forested canyon formed by Serra Creek (sometimes also depicted as Sierra Creek on topographic maps) delineates the eastern boundary of the Brazil Ranch property, which spans the Creek bottom in several sections and includes a small section of Mescal Ridge. Second-growth coast redwood stands are confined on the Brazil Ranch property to the Serra Creek canyon bottom. Predominant soil types on the Brazil Ranch include the Sheridan, the Pfeiffer-Rock Outcrop complex, and the Gamboa-Sur complex. Much of the property is covered by coarse sandy loam soils on slopes greater than $30 \%$.

A third study site was located within the 1557-hectare Landels-Hill Big Creek Reserve, situated 72 kilometers south of Monterey. Measurement plots were established in redwood stands in Devil's Canyon, next to the Redwood Camp weather station location. No major logging activities have been documented within the Big Creek Reserve [16].

\section{Methods}

A portion of the carbon cycle of coast redwood forest stands was assessed using remote sensing and field measurements to quantify the annual balance between NPP and $\mathrm{CO}_{2}$ respiration fluxes (Figure 1). Soil respiration fluxes were composed of both root and microbial $\mathrm{CO}_{2}$ emissions. Forest floor litter pools were also measured at the three study locations. 


\subsection{Field Data Collection Methods}

Hourly weather data have been collected since January 2008 at the Brazil Ranch and Big Creek sites. Air surface temperature, relative humidity, precipitation amounts, solar radiation flux, wind speed and wind direction were collected and calibrated following methods described by Tanner [17]. Soil moisture was measured at three sites as well, wherever possible, at depths of $5 \mathrm{~cm}, 10 \mathrm{~cm}, 30 \mathrm{~cm}$, and $50 \mathrm{~cm}$. Campbell Scientific CR-850 and Decagon Devices EM-50 data-loggers were programmed to collect al weather and soil moisture data by the author. Mineral soil samples were collected for laboratory analysis to a depth of $10 \mathrm{~cm}$ at study sites. At least five $3 \mathrm{~cm}$ diameter soil cores collected from the forest stands were analyzed for organic matter, mineral and texture attributes, according to methods described by Gaylak et al. [18] and Jones [19].

Soil $\mathrm{CO}_{2}$ respiration rates were measured within each redwood stand site using a infrared gas analyzer (IRGA) system (LI-8100 survey system; Li-Cor Biosciences, Lincoln, NE, USA). Flux measurements were taken at 5 randomly located soil respiration collars within the $20 \times$ 20 meter sampling area of each redwood forest stand. The respiration collars $(20 \mathrm{~cm}$ diameter; schedule 40 PVC) were securely inserted $2-3 \mathrm{~cm}$ into the forest floor at least two weeks before the beginning of sampling and were left in place for the remainder of the study period. A portable thermometer was used to measure soil temperature at $10 \mathrm{~cm}$ soil depth concurrently with soil respiration at each collar. The IRGA was calibrated daily with a certified $\mathrm{CO}_{2}$ gas standard and all measurements were corrected for changes in atmospheric pressure. For consistently in the effects of diurnal temperature variations, soil $\mathrm{CO}_{2}$ flux measurements were taken over five minute periods between 10:00 AM and 1:00 PM at each collar on each measurement date. The three redwood forest sites were visited for sampling during both dry season dates (April-October) and wet season dates (NovemberMarch) to facilitate mean yearly flux estimates for soil respiration. Forest floor litter samples, five at each site, were randomly taken during each $\mathrm{CO}_{2}$ sampling date using $20 \mathrm{~cm}$ diameter collars. All litter samples were air dried for 90 days in the laboratory and weighed.

\subsection{Modeling Methods for NPP}

As documented in Potter [20], the monthly NPP flux, defined as net fixation of $\mathrm{CO}_{2}$ by forest vegetation, was computed in CASA model on the basis of light-use efficiency [21]. Monthly production of plant biomass is estimated as a product of time-varying surface solar irradiance, $S r$, and the Enhance Vegetation index (EVI) from MODIS satellite data [22], plus a constant term for maximum light utilization efficiency $\left(e_{\max }\right)$ that is modi- fied by time-varying stress scalar terms for temperature $(T)$ and moisture $(W)$ effects (Eq.1).

$$
N P P=S r \cdot E V I \cdot e_{\max } \cdot T \cdot W
$$

The default emax term is set uniformly at 0.39 $\mathrm{g} \cdot \mathrm{C} \cdot \mathrm{MJ}^{-1}$ PAR (photosynthetically active radiation), a value that derives from calibration of predicted annual NPP to previous field estimates [8]. This model calibration has been validated globally by comparing predicted annual NPP to more than 1900 field measurements of $N P P$ [9]. Interannual NPP fluxes from the CASA model have been reported [23] and validated against multi-year estimates of NPP from field stations and tree rings [24]. Our CASA model has been validated against field-based measurements of NPP fluxes and carbon pool sizes at multiple forest sites in North America [25] and against atmospheric inverse model estimates of global carbon fluxes [9].

To optimize the fit between CASA NPP predictions with previously measured NPP estimates at the regional scale [11], the model emax term for MODIS EVI inputs had been reset to $0.55 \mathrm{~g} \cdot \mathrm{C} \cdot \mathrm{MJ}^{-1}$ PAR [9]. The regression coefficient (with line intercept forced through zero) of $R^{2}$ $=0.91$ for this global-scale NPP recalibration to 2001 MODIS EVI inputs was statistically significant $(p<$ $0.01)$.

The $T$ stress scalar is computed with reference to derivation of an optimal seasonal temperature (Topt) for plant production [8]. The $W$ stress scalar is estimated from monthly water deficits, based on a comparison of moisture supply (precipitation) to potential evapotranspiration (PET) demand using the method of Thornthwaite [26]. Water balance in the soil is modeled as the difference between precipitation or volumetric percolation inputs, monthly estimates of PET, and the drainage output for each soil layer. Inputs from rainfall can recharge the soil layers to field capacity. Excess water percolates through to lower layers and may eventually leave the system as seepage and runoff.

Monthly average spatial grids from PRISM (Parameter-elevation Regressions on Independent Slopes Model; [27]) for the year 2007 to 2010 were used for precipitation, average maximum temperature, and average minimum temperature inputs to the CASA model. These $4 \mathrm{~km}$ resolution climatologies were derived from US. weather stations records interpolated first into 30 arc-second data sets. PRISM is unique in that it incorporates a spatial climate knowledge base that accounts for topographic influences such as rain shadows, temperature inversions, and coastal effects, in the climate mapping process.

Validation of NPP predicted by CASA for California ecosystems was carried out using measured $\mathrm{CO}_{2}$ fluxes from the nearest Ameriflux tower site [11] the Tonzi Ranch site $\left(38^{\circ} 24^{\prime} 67^{\prime \prime} \mathrm{N}, 120^{\circ} 57^{\prime} 6^{\prime \prime} \mathrm{W}\right.$, at 129 m elevation; [28]) located $245 \mathrm{~km}$ northeast of Big Sur. This Ameriflux 
site was an oak savanna consisting of scattered blue oak trees (Quercus douglasii), with occasional gray pine trees (Pinus sabiniana L.), and grazed grassland (Brachypodium distachyon L., Hypochaeris glabra L., Bromus madritensis L. and Cynosurus echinatus L.). Much like the Big Sur coast, climate at the Tonzi Ranch site is Mediterranean with a mean annual temperature of $16.3^{\circ} \mathrm{C}$ and total annual precipitation of $56 \mathrm{~cm}$. Observed tower fluxes and CASA predicted monthly NPP fluxes were significantly correlated across all seasons of the Tonzi Ranch measurement period, with a coefficient of determination $\left(R^{2}\right)$ of 0.89 and root mean square error (RMSE) of $8.8 \mathrm{~g} \cdot \mathrm{C} \cdot \mathrm{m}^{-2}[11]$.

\section{RESULTS}

\subsection{CASA Predicted NPP Fluxes}

Regional model results showed the highest plant production rates for evergreen forest areas on the California Central Coast (Figure 2). A comparison of coast redwood sites indicated that the youngest forest stand (at the UCSC Campus) site had the highest predicted annual

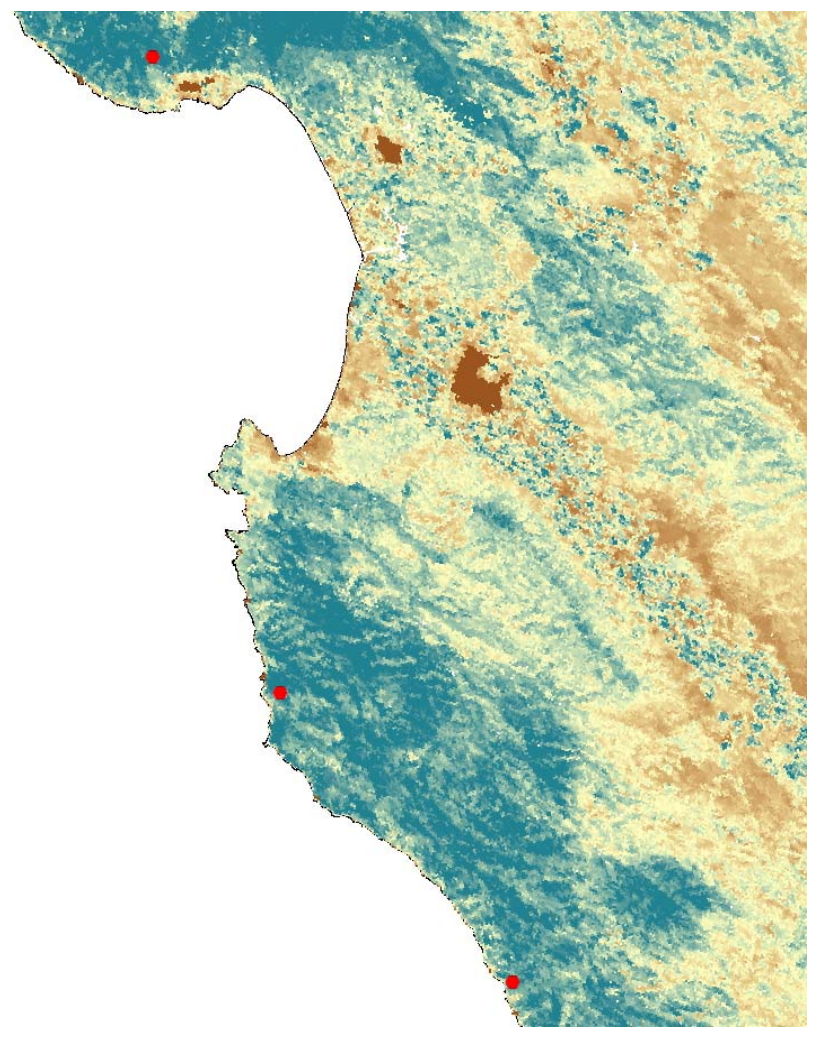

Figure 2. CASA predicted $N P P$ for the California Central Coast region surrounding Monterey Bay in May of 2007. Highest NPP values are shown for forested land cover in the dark green shades while the lowest NPP values are shown in light brown shades. The locations of three coast redwood study sites (Table 1) are labeled with red marker points, in order from north (top) to south (bottom) for the UCSC Campus, Brazil Ranch, Big Creek Reserve.
NPP from 2007 to 2010 among the three study sites (Table 2). Annual NPP was predicted to vary from 380 $\mathrm{g} \cdot \mathrm{C} \cdot \mathrm{m}^{-2} \cdot \mathrm{yr}^{-1}$ to $648 \mathrm{~g} \cdot \mathrm{C} \cdot \mathrm{m}^{-2} \cdot \mathrm{yr}^{-1}$, with the lowest productivity consistently each year estimated for the southern-most Big Creek site and intermediate annual productivity values estimated for the Brazil Ranch site.

The monthly patterns of NPP at the three coast redwood sites revealed seasonal differences in production rates that accounted for the range of predicted annual $N P P$ (Figure 3). Maximum monthly NPP fluxes and the longest sustained growing season were predicted for the northern-most (and youngest) of the redwood stands, namely at the UCSC Campus. Maximum monthly NPP flux was predicted consistently in May of each year at the Brazil Ranch and Big Creek sites, whereas peak monthly NPP flux at the UCSC Campus site was predicted to extend into June each year. Warmer monthly temperatures at the southern-most Big Creek site, and to a slightly lesser degree at the intermediate Brazil Ranch site, resulted in higher predicted stress levels to sustained redwood growth into June and July each year at these two sites compared to the UCSC Campus.

\subsection{Soil Respiration Fluxes}

Annual soil $\mathrm{CO}_{2}$ fluxes, composed of both root and microbial respiration sources, were measured to be over four times greater at the youngest UCSC Campus forest than at either the Brazil Ranch or the Big Creek forests (Table 3). These annual total fluxes are based on soil $\mathrm{CO}_{2}$ flux measurements in the range of 2 to $8 \mathrm{~g} \cdot \mathrm{C} \cdot \mathrm{m}^{-2} \cdot \mathrm{d}^{-1}$ at UCSC Campus forest and in the range of 0.5 to 2 $\mathrm{g} \cdot \mathrm{C} \cdot \mathrm{m}^{-2} \cdot \mathrm{d}^{-1}$ at Brazil Ranch and Big Creek redwood

Table 2. CASA predicted annual NPP for coast redwood sites. Units are in $\mathrm{g} \cdot \mathrm{C} \cdot \mathrm{m}^{-2} \cdot \mathrm{yr}^{-1}$.

\begin{tabular}{ccccc}
\hline Site Name & 2007 & 2008 & 2009 & 2010 \\
\hline UCSC Campus & 607 & 598 & 624 & 648 \\
Brazil Ranch & 593 & 476 & 554 & 609 \\
Big Creek Reserve & 433 & 380 & 381 & 442 \\
\hline
\end{tabular}

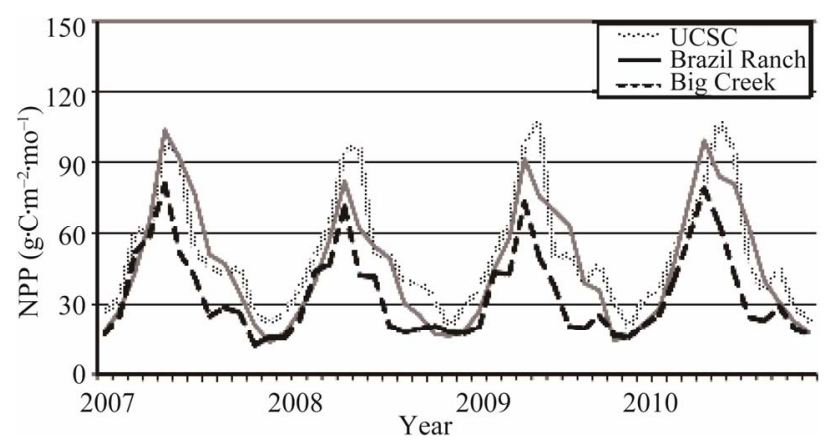

Figure 3. CASA predicted monthly NPP for coast redwood sites from 2007 to 2010 . 
Table 3. Measured soil respiration fluxes for coast redwood sites aggregated over the period 2008 to 2012. Units are in $\mathrm{g} \cdot \mathrm{C} \cdot \mathrm{m}^{-2} \cdot \mathrm{yr}^{-1}$ summarized with standard errors (SE) within sites for all measurement dates.

\begin{tabular}{cccc}
\hline Site Name & Mean & SE & $n$ (Dates) \\
\hline UCSC Campus & 1901 & 211 & 6 \\
Brazil Ranch & 386 & 50 & 6 \\
Big Creek Reserve & 481 & 55 & 2 \\
\hline
\end{tabular}

forests.

Analysis of forest soil samples showed no differences in average texture (with approximately 65\% sand and $20 \%$ clay at all sites) or in $\mathrm{pH}$ (approximately 6.1 for all soils) to account for the large soil $\mathrm{CO}_{2}$ flux differences, but we found lower average soil organic matter contents $(5.6 \%)$ at the UCSC Campus compared to the older redwood forest soils with an average of $11 \%$ organic matter.

\subsection{Forest Floor Litter Pools}

The dry weights of forest floor litter samples collected in 2009 and 2010 averaged 961, 664, and $550 \mathrm{~g} \cdot \mathrm{C} \cdot \mathrm{m}^{-2}$ $(\mathrm{SE}=162,90,67, n=10)$ at the UCSC Campus, Brazil Ranch, and Big Creek sites, respectively (SE is 1 standard error of the mean). This order from highest to lowest standing litter pool size follows the same order as annual NPP predictions for the sites (shown in Table 2), which independently confirms the CASA model plant production predictions.

\section{DISCUSSION}

For comparison to previous studies, aboveground NPP (ANPP) for northern coast California redwood stands (in Humboldt Redwoods State Park) was estimated at 7 to $10 \mathrm{Mg} \cdot \mathrm{ha}^{-1} \cdot \mathrm{yr}^{-1}$ [29], which was equivalent to ANPP of 350 to $500 \mathrm{~g} \cdot \mathrm{C} \cdot \mathrm{m}^{-2} \cdot \mathrm{yr}^{-1}$. Estimates of ANPP do not include allocation to root $N P P$, which, according to results from Long and Turner [30] for another conifer species, Douglas fir (Pseudotsuga menziesii), would underestimate total forest NPP by roughly $31 \%$ (based on the reported ANPP of $686 \mathrm{~g} \cdot \mathrm{C} \cdot \mathrm{m}^{-2} \cdot \mathrm{yr}^{-1}$ and root NPP of 308 $\mathrm{g} \cdot \mathrm{C} \cdot \mathrm{m}^{-2} \cdot \mathrm{yr}^{-1}$ at this Douglas fir site). A root NPP adjustment factor of this magnitude would put total annual NPP estimated by Busing and Fujimori [29] for coast redwood forests into a range of 507 to $725 \mathrm{~g} \cdot \mathrm{C} \cdot \mathrm{m}^{-2} \cdot \mathrm{yr}^{-1}$, which was slightly higher but still consistent with the range of CASA model predictions we reported in Table 2 for central coast redwood stands.

We measured soil respiration rates at between 0.5 to $2.2 \mathrm{~g} \cdot \mathrm{C} \cdot \mathrm{m}^{-2} \cdot \mathrm{d}^{-1}$ at Brazil Ranch and Big Creek redwood forests, which was slightly below the range of measurements reported for a 100 year-old second-growth mixed (redwood and Douglas-fir) forest of 1 to $2.4 \mathrm{~g} \cdot \mathrm{C} \cdot \mathrm{m}^{-2} \cdot \mathrm{d}^{-1}$ [31]. Total soil respiration flux was reported for this mixed conifer site at a level of $571 \mathrm{~g} \cdot \mathrm{C} \cdot \mathrm{m}^{-2} \cdot \mathrm{yr}^{-1}[31]$, which was is slightly higher than the measured fluxes we reported in Table 3 for Brazil Ranch and Big Creek redwood stands.

We hypothesize the higher soil respiration rates measured at the UCSC Campus forest site should be attributed mainly to rapid root growth and respiration activity in this young redwood stand. The lower soil organic matter content in the redwood forest soils measured at the UCSC Campus (compared to the other central coast redwood sites) suggested that turnover rate of fine roots is faster at the UCSC Campus site, due to both stand age and microclimate conditions. It is also possible that the forest stand at the UCSC Campus site has a high fraction of soil respiration derived from root growth activity (compared to the fraction from soil microbial decomposition of litter and soil C pools, per flux pathways separated in Figure 1).

Previous studies have shown that soil respiration was generally responsible for $60 \%-70 \%$ of the $\mathrm{CO}_{2}$ measured as emitted from forest ecosystems annually [32,33], with the remained attributable to aboveground plant respiration. Using $\delta^{13} \mathrm{C}$ stable isotope analysis, soil respiration for a mature coast redwood forest was partitioned into 56\% (microbial) heterotrophic activity and 44\% from (root) autotrophic activity [34]. This is in agreement with the review of Hansen et al. [35] for the root contribution to total soil respiration flux of averaging $45 \%$ in forest ecosystems. Consequently, based on the assumption that soil heterotrophic $\mathrm{CO}_{2}$ flux returns carbon to the atmosphere through decomposition of dead and downed forest biomass that was fixed previously by trees as accumulated NPP flux (as shown in Figure 1), we can conclude that the Brazil Ranch and Big Creek redwood stands are still accumulating carbon at a rate of between $100-200 \mathrm{~g} \cdot \mathrm{C} \cdot \mathrm{m}^{-2} \cdot \mathrm{yr}^{-1}$, which is not uncommon for even old-growth redwood trees [36].

\section{CONCLUSION}

Results from this study suggested that the satelliteobserved canopy variations represented can be used to quantify carbon cycling in coast redwood forest ecosystems. Despite the finding that warm monthly temperatures at the southern-most redwood forest sites resulted in elevated stress levels to sustained redwood growth into June and July each year, these redwood stands appear to sequester $\mathrm{CO}_{2}$ from that atmosphere into forest biomass for a net positive ecosystem carbon balance each year.

\section{ACKNOWLEDGEMENTS}

This work was supported by grants from NASA Ames Research. The author thanks Shuang Li for assistance with the CASA Express model 
runs, and acknowledges assistance in field sample collections from Lisa Mammel, Cole Potter, Enza Potter, and Stephen Rosenfield. NASACASA model data sets are available online at

http://geo.arc.nasa.gov/sge/casa/, as part of the Carbon Query and Evaluation Support Tools (CQUEST) project.

\section{REFERENCES}

[1] Dawson, T.E. (1998) Fog in the California redwood forest: Ecosystem inputs and use by plants. Oecologia, 117, 476-485. doi:10.1007/s004420050683

[2] Noss, R.F. (2000) The redwood forest: History, ecology and conservation of the coast redwoods. Island Press, Washington DC.

[3] Sawyer, J.O., Gray, J., West, G.J., Thornburgh, D.A., Noss, R.F., Engbeck Jr., J.H., Marcot, B.G. and Raymond, R. (2000) History of redwood and redwood forests. In: Noss, R.F., Ed., The redwood forest: History, ecology, and conservation of the coast redwoods, Island Press, Washington DC, 7-38.

[4] Lorimer, C.G., Porter, D.G., Madej, M.A., Stuart, J.D., Veirs, S.D., Norman, S.P., OHara, K.L. and Libby, W.J. (2009) Presettlement and modern disturbance regimes in coast redwood forests: Implications for the conservation of old-growth stands. Forest Ecology and Management, 258, 1038-1054. doi:10.1016/j.foreco.2009.07.008

[5] Ricketts, T.H., Dinerstein, E., Olson, D.M., Loucks, C.J., Eichbaum, W.M., DellaSala, D.A., Kavanagh, K.C., Hedao, P., Hurley, P.T., Carney, K.M., Abell, R.A. and Walters, S. (1999) A conservation assessment of the terrestrial ecoregions of North America. Island Press, Washington DC.

[6] Norman, S.P. (2007) A 500-year record of fire from a humid coast redwood forest. Report to Save-the-Redwoods League.

[7] Johnstone, J.A. and T.E. Dawson (2010) Climatic context and ecological implications of summer fog decline in the coast redwood region. Proceeding of National Academy Sciences, 107, 4533-4538. doi:10.1073/pnas.0915062107

[8] Potter, C.S., Randerson, J.T., Field, C.B., Matson, P.A., Vitousek, P.M., Mooney, H.A. and Klooster, S.A. (1993) Terrestrial ecosystem production: A process model based on global satellite and surface data. Global Biogeochemical Cycles, 7, 811-841. doi:10.1029/93GB02725

[9] Potter, C., Klooster, S., Myneni, R., Genovese, V., Tan, P. and Kumar, V. (2003) Continental scale comparisons of terrestrial carbon sinks estimated from satellite data and ecosystem modeling 1982-1998. Global and Planetary Change, 39, 201-213. doi:10.1016/j.gloplacha.2003.07.001

[10] Potter, C., Klooster, S. and Genovese, V. (2012) Net primary production of terrestrial ecosystems from 2000 to 2009. Climatic Change. doi:10.1007/s10584-012-0460-2

[11] Li, S., Potter, C.S. and Hiatt, C. (2012) Monitoring of net primary production in California rangelands using Landsat and MODIS satellite remote sensing. Natural Resources, 3, 56-65.

[12] Zhao, M. and Running, S.W. (2010) Drought-induced reduction in global terrestrial net primary production from 2000 through 2009. Science, 329, 940-943. doi:10.1126/science. 1192666

[13] Henson, P. and Usner, D.J. (1996) The natural history of big sur. University of California Press, Berkeley.

[14] Li, S. and Potter, C.S. (2012) Patterns of aboveground biomass regeneration in post-fire coastal scrub communities. GIScience \& Remote Sensing, 49, 182-201.

[15] Warrick, S.F. (1982) The natural history of the UC Santa Cruz campus, environmental field program. University of California, Santa Cruz.

[16] Bickford, C. and Rich, P. (1984) Vegetation and flora of the landels-hill big creek reserve Monterey county, California. 2nd Edition, Environmental Field Program University of California, Santa Cruz.

[17] Tanner, B.D. (1990) Automated weather stations. Remote Sensing Reviews, 5, 73-98. doi: $10.1080 / 02757259009532123$

[18] Gavlak, R., Horneck, D., Miller, R.O. and KotubyAmacher, J. (2003) Soil, plant, and water reference methods for the Western region. 2nd Edition, WCC-103 Publication, Corvallis.

[19] Jones Jr., J.B. (2001) Laboratory guide for conducting soil tests and plant analysis. CRC Press, Boca Raton.

[20] Potter, C.S. (1999) Terrestrial biomass and the effects of deforestation on the global carbon cycle. BioScience, 49, 769-778. doi: $10.2307 / 1313568$

[21] Monteith, J.L. (1972) Solar radiation and productivity in tropical ecosystems. Journal of Applied Ecology, 9, 747766. doi:10.2307/2401901

[22] Huete, A., Didan, K., Miura, T., Rodriguez, E.P., Gao, X. and Ferreira, L.G. (2002) Overview of the radiometric and biophysical performance of the MODIS vegetation indices. Remote Sensing of Environment, 83, 195-213. doi:10.1016/S0034-4257(02)00096-2

[23] Behrenfeld, M.J., Randerson, J.T., McClain, C.R., Feldma, G.C., Los, S.Q., Tucker, C.I., Falkowski, P.G., Field, C.B., Frouin, R., Esaias, W.E., Kolber, D.D. and Pollack, N.H. (2001) Biospheric primary production during an ENSO transition. Science, 291, 2594-2597. doi:10.1126/science.1055071

[24] Malmström, C.M., et al. (1997) Interannual variation in global scale net primary production: Testing model estimates. Global Biogeochemical Cycles, 11, 367-392.

[25] Amthor, J.S., et al. (2001) Boreal forest $\mathrm{CO}_{2}$ exchange and evapotranspiration predicted by nine ecosystem process models: Inter model comparisons and relations to field measurements. Journal of Geophysical Research, 106, 623-648. doi:10.1029/2000JD900850

[26] Thornthwaite, C.W. and Mather, J.R. (1955) The water balance. Publications in Climatology, Centerton.

[27] Daly, C., et al. (2004) Up-to-date monthly climate maps for the conterminous United States. Proceeding of 14th AMS Conference on Applied Climatology, 84th AMS Annual Meeting Combined Preprints, Seattle, 13-16 January 2004.

[28] Baldocchi, D.D., Xu, L.K. and Kiang, N. (2004) How 
plant functional-type, weather, seasonal drought, and soil physical properties alter water and energy fluxes of an oak-savanna and an annual grassland. Agricultural and Forest Meteorology, 123, 13-39. doi:10.1016/j.agrformet.2003.11.006

[29] Busing, R.T. and Fujimori, T. (2005) Biomass, production and woody detritus in an old coast redwood (Sequoia sempervirens) forest. Plant Ecology, 177, 177-188. doi:10.1007/s11258-005-2322-8

[30] Long, J.N. and Turner, J. (1975) Aboveground biomass of understorey and overstorey in an age sequence of four Douglas-fir stands. Journal of Applied Ecology, 12, 179188. doi: $10.2307 / 2401727$

[31] Sanderman, J. and Amundson, R. (2008) A comparative study of dissolved organic carbon transport and stabilization in California forest and grassland soils. Biogeochemistry, 89, 309-327. doi:10.1007/s10533-008-9221-8

[32] Malhi, Y., Baldocchi, D.D. and Jarvis, P.G. (1999) The carbon balance of tropical, temperate and boreal forests. Plant Cell and Environment, 22, 715-740. doi:10.1046/j.1365-3040.1999.00453.x

[33] Steinmann, K., Siegwolf, R.T., Saurer, M. and Körner, C. (2004) Carbon fluxes to the soil in a mature temperate forest assessed by ${ }^{13} \mathrm{C}$ isotope tracing. Oecologia, 141, 489-501. doi:10.1007/s00442-004-1674-4

[34] Tu, K.P. and Dawson, T.E. (2005) Partitioning ecosystem respiration using stable carbon isotope analyses of $\mathrm{CO}_{2}$. In: Flanagan, L.B., Ehleringer, J.R. and Pataki, D.E., Eds., Stable isotopes and biosphere-atmosphere interactions: processes and biological controls, Elsevier, Amsterdam, 125-153.

[35] Hanson, P.J., Edwards, N.T., Garten, C.T. and Andrews, J.A. (2000) Separating root and soil microbial contributions to soil respiration: A review of methods and observations. Biogeochemistry, 48, 115-146. doi:10.1023/A:1006244819642

[36] Sillett, S.C., et al. (2010) Increasing wood production through old age in tall trees. Forest Ecology and Management, 259, 976-994. doi:10.1016/j.foreco.2009.12.003 